\title{
Pengaruh Likuiditas, Profitabilitas dan Leverage terhadap Prediksi Financial Distress
}

${ }^{1}$ Rina Erayanti

Universitas Pancasila, Indonesia

\section{N F O A R T I K E L}

JEL Classification:

M40

G18

\section{Keywords:}

liquidity, profitability, leverage, financial distress.

\begin{abstract}
A B S T R A C T
The importance of financial management as a vital aspect of the company should be considered and managed properly if the company remains to maintain the sustainable business. Development of an early warning system model is needed to anticipate the financial distress, because this model can identify and improve the condition prior to the crisis. This research aims to examine the liquidity $(C R, Q R)$, profitability $(R O I, R O E)$, leverage (DER, $D A R)$, the effect of financial distress. The sample used in this research is the company's transportation, infrastructure and utilities sector in Indonesia Stock Exchange (BEI) for the period year 2012-2016. This research uses purposive sampling, which obtained 171 samples of observations from 39 companies. The hypothesis is examined by using regression logistic. The result shows that the ratio of ROI havesignificant effect on the company's financial distress. While the $C R, Q R, R O E D E R$ and DAR have no effect on the company's financial distress.
\end{abstract}

\section{A B S T R A K}

Pentingnya pengelolaan keuangan sebagai aspek vital perusahaan benar-benar harus diperhatikan dan dikelola dengan baik jika perusahaan tetap untuk dapat menjaga kelangsungan hidup usahanya. Diperlukan pengembangan model sistem peringatan untuk mengantisipasi adanya financial distress, karena model ini dapat digunakan sebagai sarana untuk mengidentifikasikan bahkan untuk memperbaiki kondisi sebelum sampai pada kondisi krisis. Studi ini bertujuan untuk meneliti pengaruh likuiditas (CR, QR), profitabilitas (ROI, ROE), leverage (DER, DAR), terhadap prediksi financial distress pada perusahaan sektor transportasi, infrastruktur dan utilities yang terdaftar di Bursa Efek Indonesia periode tahun 2012-2016. Pengambilan sampel dengan menggunakan purposive sampling dan diperoleh sebanyak 171 sampel observasi dari 39 perusahaan. Pengujian hipotesis dilakukan dengan menggunakan regression logistik. Hasil pengujian hipotesis mununjukkan bahwa variabel ROI berpengaruh signifikan terhadap financial distress perusahaan. Sedangkan variabel $C R, \quad Q R, \quad R O E, D E R$ dan DAR tidak berpengaruh terhadap financial distress perusahaan. 


\section{Pendahuluan}

Keuangan perusahaan merupakan pilar yang sangat penting untuk kemajuan sebuah perusahaan, sebab kebanyakan kasus kebangkrutan usaha bermula dari adanya financia ldistress yang disebabkan oleh buruknya pengelolaan keuangan. Pentingnya pengelolaan keuangan sebagai aspek vital perusahaan harus benar-benar diperhatikan dan dikelola dengan baik jika perusahaan tetap untuk dapat menjaga kelangsungan hidup usahanya. Model sistem peringatan untuk mengantisipasi adanya financial distress perlu untuk dikembangkan, karena model ini dapat digunakan sebagai sarana untuk mengidentifikasikan bahkan untuk memperbaiki kondisi sebelum sampai pada kondisi krisis.Widarjo dan Setiawan (2009) mendefinisikan financial distress sebagai tahap penurunan kondisi keuangan yang terjadi sebelum terjadinya kebangkrutan ataupun likuidasi. Widarjo dan Setiawan (2009) menyatakan kegunaan informasi jika perusahaan mengalami financial distress adalah:

1. Dapat mempercepat tindakan manajemen untuk mencegah masalah sebelum terjadinya kebangkrutan.

2. Pihak manajemen dapat mengambil tindakan merger atau take over agar perusahaan lebih mampu untuk membayar hutang dan mengelola perusahaan dengan lebih baik.

3. Memberikan tanda peringatan awal adanya kebangkrutan pada masa yang akan datang.

Melihat pentingnya financial distress bagi pihak internal dan eksternal perusahaan dengan melakukan penelitian terkini terhadap financial distress bagi para pihak. Berbagai penelitian telah dikembangkan untuk mengetahui bagaimana cara memprediksi financial distress atau kebangkrutan perusahaan. Penelitian terdahulu mengemukakan salah satu cara dengan memanfaatkan analisis rasio keuangan. Menurut Altman (2010),In general, ratios measuring profitability, liquidity, leverage, and solvency, and multi dimensional measures, like earnings and cash flow coverage, prevailed as the most significant indicators. Nindita K, Moeljadi dan Indrawati (2014) dalam penelitiannya mengatakan prediksi financial distress sebagai peringatan awal sangat penting untuk mengantisipasi financial distress di perusahaan. Menurut Ross (2009), tekanan keuangan adalah situasi dimana arus kas operasi perusahaan tidak cukup untuk memenuhi kewajiban lancar. Kesulitan keuangan dapat menyebabkan perusahaan gagal bayar dalam kontrak, dan mungkin melibatkan restrukturisasi keuangan antara perusahaan, krediturnya, dan investor ekuitasnya. Praktisnya, prediksi financial distress tidak hanya diterapkan pada perusahaan yang memiliki kondisi tertentu, tapi juga semua perusahaan yang memiliki kondisi baik atau buruk karena tujuan financial distress adalah sebagai sebuah sistem peringatan awal sebelum kebangkrutan terjadi dan perusahaan dapat mengambil tindakan dalam menghindarinyadan perbaiki keuangannya. Untuk mendeteksi financial distress suatu perusahaan dapat digunakan analisis rasio keuangan. Secara umum rasio-rasio seperti profitabilitas, likuiditas, leverage dan cakupan arus kas berlaku sebagai indikator yang paling signifikan dalam memprediksi kesulitan keuangan maupun kebangkrutan.

Penelitian oleh Nindita K, Moeljadi \& Indrawati(2014) dan Ayu (2016) curren tratio berpengaruh signifikan untuk memprediksi financial distress. Sedangkan penelitian yang dilakukan oleh Lakshan \& Wijekoon (2017), Alkhatib \& Al-Horani (2012), current ratio tidak memiliki pengaruh yang signifikan untuk memprediksi financial distress. Sama halnya dengan current ratio menurut Lakshan \& Wijekoon (2017), Al-khatib \& Al-Horani (2012), quick ratio tidak memiliki pengaruh yang signifikan untuk memprediksi financial distress. Namun penelitian yang dilakukan oleh Ayu (2016) serta Gilbert \& Edmond (2009), quick ratio memiliki pengaruh signifikan untuk memprediksi financial distress.

Rasio profitabilitas merupakan rasio yang menggambarkan kemampuan perusahaan dalam mendapatkan laba melalui semua kemampuan dan sumber yang ada seperti kegiatan penjualan, kas, modal, jumlah karyawan, jumlah cabang dan sebagainya Brigham \& Houston (2006). Dengan kata lain rasio profitabilitas adalah rasio yang mengukur atau menilai kemampuan perusahaan dalam memperoleh keuntungan melalui berbagai aktivitas yang dilakukan oleh perusahaan. Dalam penelitian ini rasio yang digunakan untuk mengukur financial distress adalah rasio return on investment (ROI), ROI ini sering disebut return on total assets dipergunakan untuk mengukur kemampuan perusahaan dalam menghasilkan keuntungan dengan menggunakan keseluruhan aktiva yang dimilikinya dan return on equity (ROE) disebut juga dengan laba atas equity. Dibeberapa referensi disebut juga dengan rasio total asset turnover atau perputaran total aset. Penelitian 
yang dilakukan oleh Al-khatib \& Al-Horani (2014) return on asset dan return on equity,memiliki pengaruh signifikan untuk memprediksi financial distress. Penelitian oleh Lakshan \& Wijekoon (2017), serta Keener (2013), menyatakan return on asset memiliki pengaruh signifikan untuk memprediksi financial distress sementara return on equity tidak memiliki pengaruh yang signifikan.

Penelitian yang dilakukan olehLakshan \& Wijekoon (2017), Al-khatib \& Al-Horani (2014), Gilbert \& Edmond (2009), serta Keener (2013), debt to equity ratio memiliki pengaruh signifikan untuk memprediksi financial distress. Adel et al (2016), debt to equity ratio tidak memiliki pengaruh signifikan untuk memprediksi financial distress. Sama halnya dengan penelitian yang dilakukan oleh Nindita K, Moeljadi \& Indrawati (2014), Lakshan \& Wijekoon (2017) dan Al-khatib \& AlHorani (2014) debt to asset ratio memiliki pengaruh signifikan untuk memprediksi financial distress. Bhunia \& Sarkar (2011), debt to asset ratio tidak memiliki pengaruh signifikan untuk memprediksi financial distress.

\section{Telaah Teori dan Pengembangan Hipotesis Pengaruh Current Ratio terhadap Prediksi Financial Distress Perusahaan}

Current ratio menurut Shanjaya\& Marlius (2017) merupakan perbandingan antara aset lancar dengan kewajiban lancar.Rasio ini menunjukkan kemampuan perusahaan untuk membayar kewajiban jangka pendeknya dengan menggunakan aktiva lancarnya. Current ratio merupakan indikator likuiditas yang dipakai secara luas, dengan alasan selisih lebih aset lancar di atas hutang lancar merupakan suatu jaminan terhadap kemungkinan rugi yang timbul dari usaha dengan cara merealisasikan aset lancar nonkas menjadi kas. Semakin besar jumlah jaminan yang tersedia untuk menutup kemungkinan rugi, kesulitan keuangan akan semakin terhindar.

Ijaz et al (2013) dalam penelitiannya menemukan bahwa dengan menggunakan current ratio dan Z-Score merupakan prediktor yang baik untuk menilai kesehatan keuangan perusahaan sektor gula yang terdaftar di bursa efek Karachi.Studi ini memberikan bukti bahwa model ini dapat diterima sebagai alat yang andal. Dengan demikian variabel current ratio mempunyai pengaruh negatif terhadap prediksi financial distress perusahaan. Dalam penelitian ini penulis ingin menguji kembali variabel tersebut apakah memiliki hasil yang sama atau berbeda dengan penelitian terdahulu. Dari uraian diatas dapat disimpulkan hipotesis sebagai berikut:

$\mathbf{H}_{1}$ : Current ratio berpengaruh terhadap prediksi financial distress

Pengaruh Quick Ratio terhadap Prediksi Financial Distress Perusahaan

Quick ratio merupakan ukuran kemampuan perusahaan dalam memenuhi kewajiban jangka pendeknya dengan tidak memperhitungkan persediaan, karena persediaan biasanya dianggap merupakan aset yang tidak likuid. Hal ini berkaitan dengan panjangnya waktu persediaan tersebut untuk menjadi kas. Persediaan merupakan unsur aktiva lancar yang likuiditasnya rendah dan sering mengalami fluktuasi harga serta menimbulkan kerugian jika terjadi likuiditas.

Arlyana et al (2015), evaluasi statistik terhadap beberapa perusahaan non keuangan quick ratio merupakan salah satu indikator yang dapat memberi sinyal awal pada tekanan atau kerentanan pada sektor korporasi non-keuangan. Bahwa semakin besar quick ratio maka semakin baik kondisi perusahaan, karena rasio ini merupakan rasio yang menunjukkan kemampuan aktiva lancar yang paling likuid mampu menutupi hutang lancar Sawir (2009).

Gilbert dan Edmond (2009), rasio keuangan itu berguna dan akan memberikan informasi pengambilan keputusan yang berharga tentang bisnis jika digunakan secara cerdas dan dengan penilaian yang baik. Menurut Gilbert rasio keuangan saling terkait antara satu sama lain dan kombinasi berbagai rasio keuangan akan lebih baik untuk memprediksi financial distress dan kebangkrutan. Empat indikator rasio yang paling signifikan untuk memprediksi financial distress dan kebangkrutan; net profit-total assets, operating profit-turnover, quick ratio dan long term debt-total equity. Dengan demikian variabel quick ratio mempunyai pengaruh terhadap kondisi financial distress perusahaan. Dalam penelitian ini penulis ingin menguji kembali variabel tersebut apakah memiliki hasil yang samaatau berbeda dengan penelitian terdahulu. Dari uraian diatas dapat disimpulkan hipotesis sebagai berikut:

$\mathbf{H}_{2}$ : Quick ratio berpengaruh terhadap prediksi financial distress

Pengaruh Return on Investment terhadap
Prediksi Financial Distress Perusahaan
Menurut Sutrisno (2009), return on
investment (ROI) adalah suatu ukuran
kemampuan perusahaan dalam menghasilkan Magister Akuntansi Universitas Pancasila 
keuntungan yang digunakan untuk menutup investasi yang telah dikeluarkan. ROI merupakan rasio yang menunjukkan hasil dari jumlah aktiva yang digunakan dalam perusahaan atau suatu ukuran tentang efisiensi manajemen. Rasio ini menunjukkan hasil dari seluruh aktiva yang dikendalikan dengan mengabaikan sumber pendanaan, rasio ini biasanya diukur dengan persentase.

Kendala keuangan didefinisikan secara bulat sebagai premi risiko yang harus ditanggung perusahaan untuk meningkatkan dana eksternal, atau sebagai akses terbatas terhadap dana pinjaman. Pembiayaan eksternal akan investasi tersebut menyebabkan menaikkan biaya dan menurunkan permintaan modal yang baru. Hal ini akan menurunkan perkiraan keuntungan di masa depan probabilitas dan dengan demikian akan mengurangi permintaan investasi perusahaan juga. Perusahaan yang menghadapi biaya lebih tinggi untuk keuangan eksternal dan terancam risiko kebangkrutan. Dengan demikian variabel ROI mempunyai pengaruh negatif terhadap kondisi financial distress perusahaan.Dalam penelitian ini penulis ingin menguji kembali variabel tersebut apakah memiliki hasil yang sama atau berbeda dengan penelitian terdahulu. Dari uraian diatas dapat disimpulkan hipotesis sebagai berikut:

$\mathbf{H}_{3}$ : Return on investment berpengaruh terhadap prediksi financial distress

\section{Pengaruh Return on Equity terhadap Prediksi Financial Distress Perusahaan}

Menurut Brigham \& Houston (2006) return on equityuntuk mengukur daya perusahaan dalam menghasilkan laba pada investasi nilai buku pemegang saham. ROE menunjukkan kemampuan perusahaan dalam menghasilkan laba setelah pajak dengan menggunakan modal sendiri yang dimiliki perusahaan. Kamaludin dan Pribadi (2011), dalam hasil penelitiannyaROE dapat digunakan untuk memprediksi kondisi financial distress suatu perusahaan, sehingga dengan hasil yang ada perusahaan dapat menghindari gejala-gejala timbulnya kepailitan, dan perusahaan dapat mengetahui dengan baik bahwa gejala-gejala perusahaan yang akan pailit dapat dideteksi.

Rasio ini penting bagi pemegang saham untuk mengetahui efektivitas dan efisiensi pengelolaan modal sendiri yang dilakukan oleh pihak manajemen perusahaan. Semakin tinggi rasio ini berarti semakin efektif dan efisien perusahaan dalam mengelola modal yang dimilikinya yang menyebabkan probabilitas untuk mengalami financial distress semakin kecil dan apabila nilai ROE semakin kecil maka semakin tidak efektif dan tidak efisien perusahaan dalammengelola modalnya yang menyebabkan tingkat probabilitas untuk mengalami financial distress semakin tinggi. Dalam penelitian ini penulis ingin menguji kembali variabel tersebut apakah memiliki hasil yang sama atau berbeda dengan penelitian terdahulu. Dari uraian diatas dapat disimpulkan hipotesis sebagai berikut:

$\mathbf{H}_{4}$ : Return on equity berpengaruh terhadap prediksifinancial distress

\section{Pengaruh Debt to Equity Ratio terhadap Prediksi Financial Distress Perusahaan}

Debt to equity ratio menurut Darsono (2005), yaitu merupakan salah satu rasio leverage atau solvabilitas. Rasio solvabilitas adalah rasio untuk mengetahui kemampuan perusahaan dalam membayar kewajiban jika perusahaan tersebut dilikuidasi. Rasio ini juga disebut dengan rasio pengungkit (Leverage) yaitu menilai batasan perusahaan dalam meminjam uang. Rasio ini dicari dengan cara membandingkan antara keseluruhan utang, termasuk utang lancar dengan seluruh ekuitas (Shanjaya \& Marlius, 2017).

Kriscahyadi (2011), mengatakan bahwa dengan semakin meningkatnya debt to equity ratio (dimana beban utang juga semakin besar), hal tersebut berdampak terhadap profitabilitas yang diperoleh perusahaan, karena sebagian digunakan untuk membayar bunga pinjaman. Biaya bunga yang semakin besar, maka akan semakin mengurangi profitabilitas (earning after tax), maka hak para pemegang saham (dividen) juga semakin berkurang. Penggunaan utang yang terlalu tinggi akan menyebabkan penurunan dividen yang mana sebagian besar keuntungan akan dialokasikan sebagai cadangan pelunasan utang yang nantinya akan menyebabkan terjadinya financial distress. Dalam penelitian ini penulis ingin menguji kembali variabel tersebut apakah memiliki hasil yang sama atau berbeda dengan penelitian terdahulu. Dari uraian diatas dapat disimpulkan hipotesis sebagai berikut:

$\mathbf{H}_{5}$ : Debt to equity ratio berpengaruh terhadap prediksi financial distress

Pengaruh Debt to Asset Ratio terhadap Prediksi Financial Distress Perusahaan 
Menurut Handayani (2013) menyatakan debt to asset ratio adalah rasio yang menunjukkan sejauh mana utang dapat ditutupi oleh aktiva lebih besar rasionya lebih aman (solvable). Bisa juga dibaca beberapa porsi utang dibandingkan aktiva.Sama dengan debt to equity ratio, manfaat dari analisis debt to asset ratio. Karena kedua rasio ini merupakan rasio leverage yang untuk memilih menggunakan modal sendiri atau modal pinjaman haruslah menggunakan beberapa perhitungan. Seperti diketahui bahwa penggunaan modal sendiri atau dari modal pinjaman akan memberikan dampak tertentu bagi perusahaan. Pihak manajemen harus pandai mengatur debt to equity ratio. Pengaturan rasio yang baik akan memberikan banyak manfaat bagi perusahaan guna menghadapi segala kemungkinan yang akan terjadi termasuk financial distress. Namun semua kebijakan tergantung dari tujuan perusahaan secara keseluruhan.Widarjo dan Doddy Setiawan (2009) dalam penelitiannya menyatakan debt to asset ratio berpengaruh terhadap financial distress sama halnya dengan hasil penelitian yang dilakukan oleh Nindita K, Moeljadi dan Indrawati (2014), Lakshan dan Wijekoon (2017) dan Al-khatib dan Al-Horani (2014) debt to asset ratio memiliki pengaruh signifikan untuk memprediksi financial distress. Dalam penelitian ini penulis ingin menguji kembali variabel tersebut apakah memiliki hasil yang sama atau berbeda dengan penelitian terdahulu. Dari uraian diatas dapat disimpulkan hipotesis sebagai berikut:

$\mathbf{H}_{6}$ : Debt to asset ratio berpengaruh terhadap prediksi financial distress

\section{Metode Penelitian}

Adapun kriteria-kriteria penentuan sampel yang digunakan dalam penelitian ini adalah sebagai berikut :

1. Perusahaan sektor transportasi, infrastruktur dan utilities yang terdaftar di BEI selama periode pengamatan, yaitu tahun 2012-2016.

2. Perusahaan tidak keluar (delisting) dari BEI selama periode pengamatan tahun 2012-2016.

3. Perusahaan menerbitkan laporan keuangan secara rutin dalam rentang tahun penelitian yaitu tahun 2012-2016 dan periode pelaporan berakhir 31 Desember.

Populasi dalam penelitian ini yaitu perusahaan sektor transportasi, infrastruktur dan utilities yang terdaftar di BEI yang berjumlah 60 perusahaan. Pada penelitian ini menggunakan purposive sampling dengan kriteria di atasdan setelah data perusahaan didokumentasikan sesuai dengan kriteria yang telah ditetapkan, maka diperoleh sampel dalam penelitian ini yaitu sebanyak 39 perusahaan dengan periode penelitian yaitu periode tahun 2012 sampai dengan tahun 2016.

Definisi operasional variabel penelitian merupakan penjelasan dari masing-masing variabel yang digunakan dalam penelitian terhadap indikator-indikator yang membentuknya. Definisi operasional penelitian ini dapat dilihat pada tabel berikut ini:

\begin{tabular}{|c|c|c|c|c|}
\hline No & $\begin{array}{c}\text { Jenis } \\
\text { Variabel }\end{array}$ & Rumus & Indikator & Skala \\
\hline 1. & $\begin{array}{l}\left(\mathrm{X}_{1}\right) \\
\text { Current } \\
\text { Ratio }\end{array}$ & $\frac{\text { CurrentAsset }}{\text { CurrentLiabilities }}$ & $\begin{array}{l}\text { Jika hasilnya } \\
\text { menunjukkan } \\
\text { CR 1:1 atau 100\% } \\
\text { artinya aktiva } \\
\text { lancar dapat } \\
\text { menutupi } \\
\text { kewajiban jangka } \\
\text { pendek dan akan } \\
\text { lebih aman jika } \\
\text { rasio lancar diatas } \\
\text { satu atau diatas } \\
\text { 100\% maka akan } \\
\text { perusahaan akan } \\
\text { mampu } \\
\text { membayar } \\
\text { hutang lancarnya }\end{array}$ & Ratio \\
\hline
\end{tabular}


Rina Erayanti : Pengaruh Likuiditas, Profitabilitas dan Leverage terhadap Prediksi Financial Distress

2. $\left(X_{2}\right)$

Quick Ratio

$$
\frac{\text { CurrentAssets - Inventory }}{\text { CurrentLiabilities }}
$$

3. $\left(\mathrm{X}_{4}\right)$

Return on

Investment

4. $\quad\left(\mathrm{X}_{4}\right)$

Return on $\left(\frac{\text { Laba Setelah Pajak }}{\text { Ekuitas }}\right) \times 100 \%$

\author{
$\left(\frac{\text { Laba Setelah Pajak }}{\text { Investasi }}\right) \times 100 \%$
}

Equity tanpa

menggangguoper

asi perusahaan.

Jika suatu

perusahaan Ratio

mempunyai nilai

QRkurang dari

$100 \%$ atau $1: 1$, hal

ini dianggap

kurang baik

tingkat

likuiditasnya.

Jikahasil

perhitungan ROI Ratio

bernilai negatif

maka investasi

tersebut

merupakan

kerugian.

Sebaliknya, jika

ROI bernilai

positif maka

investasi tersebut

menguntungkan.

Semakin besar

nilaiROI maka

akan semakin

baik, karena

dengan demikian

berarti

perusahaan dapat

menghasilkan

laba yang tinggi

dengan

menggunakan

total aset yang

dimilikinya.

Jika hasil

perhitungan ROE Ratio

mendekati 1,

maka

menunjukkan

efektifitas dan

efisiensi

perusahaan

dalam

menghasilkan

pendapatan. Jika

nilai ROE

mendekati 0 ,

maka perusahaan

tidak dapat

mengelola modal

dengan efisien 
5.

$$
\left(X_{5}\right)
$$

Debt to

Equity Ratio

6. $\left(\mathrm{X}_{6}\right)$

Debt to

Asset Ratio $\frac{\text { Total Hutang (Debt) }}{\text { Ekuitas (Equity) }}$

Total Hutang (Debt) untuk

mendapatkan

penghasilan. Nilai

ROE yang tinggi

akan

menyebabkan

posisi pemilik

modal

perusahaan

semakin kuat.

Jika hasil

penghitungan

Debt to Equity

Ratio semakin

besar rasio ini

bagi bank

(kreditor), akan

semakin tidak

menguntungkan

karena akan

semakin besar

resikoyang

ditanggung atas

kegagalan yang

mungkin terjadi

di perusahaan.

Sebaliknya

dengan rasio

yang rendah,

semakin tinggi

tingkat

pendanaan yang

disediakan

pemilik akan

semakin besar

batas

pengamanan bagi

peminjam jika

terjadi kerugian

atau penyusutan

terhadap nilai

aktiva.

Jika hasil

penghitungan

Ratio

Debt to Asset Ratio

semakin tinggi

rasio ini berarti

semakin besar

jumlah modal

pinjaman yang

digunakan untuk

investasi pada

aktiva guna

menghasilkan
Ratio

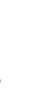


7.

$(\mathrm{Y})$

Financial Distress keuntungan bagi

perusahaan.

Indikator negatif Rasio

skornya adalah

1(satu) dan jika

positif, skornya 0 .

Perkalian antara

nilaidan skor $=$

jumlah total yang

menentukan

apakah

perusahaan

dikategorikan

dalam Financial

distress atau Non

financial distress.

Berdasarkan

jumlahnya jika:

a. Total angka

$\geq 3$ :

perusahaan

dikategorikan

dalam kondisi

FD

b. Jumlah total

$<3$ :

perusahaan

dikategorikan

dalam kondisi

NFD
Analisis statistik deskriptif digunakan untuk mengetahui karakteristik sampel yang digunakan dan menggambarkan variabel-variabel dalam penelitian. Analisis statistik deskriptif meliputi jumlah, sampel, nilai minimum, nilai maksimum, nilai rata-rata (mean) dan standar deviasi.

Pengujian hipotesis dalam penelitian ini menggunakan analisis multivariate dengan menggunakan regresi logistik (logistic regretion)yang variabel bebasnya merupakan kombinasi antara metrik dan non metrik (nominal).Variabel ini menggunakan variabel dummy dengan pengukuran: 1 (satu)=Financial Distressdan $0(\mathrm{nol})=$ Non Financial Distress.

\section{Hasil dan Pembahasan Analisis Deskriptif}

Hipotesis dalam penelitian ini diuji dengan menggunakan model regresi logistik (logistic regression). Analisa deskriptif dilakukan agar dapat memberikan gambaran terhadap variabelvariabel yang digunakan dalam penelitian.Di dalam penelitian ini yang merupakan variabel independen adalah faktor-faktor yang dapat berperan dalamcurrent ratio (CR), quick ratio $(Q R)$, return on investment (ROI), return on equity (ROE), debt to equity ratio (DER), debt to asset ratio (DAR). Sedangkan variabel dependen penelitian ini adalah financial distress dengan menggunakan tiga indikator yaitu,cash flow (CF), net operating income (NOI), earning per share (EPS).

Perhitungan statistik deskriptif digunakan untuk mengetahui karakteristik dari sampel penelitian yang digunakan atau dianalisis lebih lanjut. Perhitungan yang dilakukan meliputi jumlah sampel, standar deviasi, nilai minimum dan nilai maximum. Pengolahan data dengan bantuan Statistical Product and Service Solutions for Windows Version 24 and Microsoft Excel 2013. 
Tabel 4.1 Hasil Uji Koefisien Regresi (Parsial)

\begin{tabular}{|c|c|c|c|c|c|c|c|}
\hline \multicolumn{8}{|c|}{ Variables in the Equation } \\
\hline & & B & S.E. & Wald & df & Sig. & $\operatorname{Exp}(B)$ \\
\hline \multirow[t]{10}{*}{ Step 1a } & CR & - & 16.899 & 1.588 & 1 & .208 & .000 \\
\hline & & 21.299 & & & & & \\
\hline & QR & 20.163 & 16.869 & 1.429 & 1 & .232 & 571130493.300 \\
\hline & ROI & - & 32.824 & 10.396 & 1 & .001 & .000 \\
\hline & & $\begin{array}{r}105.83 \\
3\end{array}$ & & & & & \\
\hline & $\mathrm{ROE}$ & - & 12.014 & 1.219 & 1 & .270 & .000 \\
\hline & & 13.266 & & & & & \\
\hline & DER & -.012 & .308 & .001 & 1 & .969 & .988 \\
\hline & DAR & -.999 & 1.263 & .625 & 1 & .429 & .368 \\
\hline & Constant & 1.806 & 1.683 & 1.152 & 1 & .283 & 6.089 \\
\hline
\end{tabular}

a. Variable(s) entered on step 1: CR, QR, ROI, ROE, DER, DAR.

Sumber: data olahan SPSS

Hasil pengujian hipotesis secara keseluruhan disajikan pada Tabel 4.2 sebagai berikut:

Gambar 4.2: Ringkasan Hasil Pengujian Hipotesis

\begin{tabular}{|l|l|l|}
\hline & \multicolumn{1}{|c|}{ Hipotesis } & \multicolumn{1}{|c|}{ Hasil } \\
\hline $\mathrm{H}_{1}$ & Current ratio berpengaruh terhadap prediksi financial distress & Not Sign \\
\hline $\mathrm{H}_{2}$ & Quick ratio berpengaruh terhadap prediksi financial distress & Not Sign \\
\hline $\mathrm{H}_{3}$ & Return on investment berpengaruh terhadap pediksi financial distress & Sign \\
\hline $\mathrm{H}_{4}$ & Return on equity berpengaruh terhadap prediksi financial distress & Not Sign \\
\hline $\mathrm{H}_{5}$ & Debt to equity ratio berpengaruh terhadap prediksi financial distress & Not Sign \\
\hline $\mathrm{H}_{6}$ & Debt to asset ratio berpengaruh terhadap prediksi financial distress & Not Sign \\
\hline & & \\
\hline
\end{tabular}

\section{Hasil Uji Hipotesis}

Penelitian ini merupakan studi mengenai prediksi financial distress yaitu asumsi yang menyatakan bahwa suatu entitas dapat terus beroperasi mempertahankan kelangsungan hidupnya dalam jangka waktu lama. Penelitian ini mengamati 6 variabel yaitu current ratio (CR), quick ratio $(Q R)$, return on investment $(R O I)$, return on equity (ROE), debt to equity ratio (DER), debt to asset ratio (DAR).

Penelitian terhadap 39 perusahaan yang terdapat di Bursa Efek Indonesia yang diprediksi mengalami financial distress yang dipilih dengan metode purposive sampling selama tahun 2012 sampai tahun 2016 dengan tahun pengamatan 5 tahun. Total pengamatan yang dijadikan sampel penelitian adalah 39 perusahaan dikalikan 5 tahun penelitian berjumlah 195 sampel. Setelah dilakukan casewise diagnostics testhasil uji tersebut diketahui sebanyak 24 sampel merupakan data outlier sehingga harus dikeluarkan dari model penelitian sehingga sampel penelitian berjumlah 171 data perusahaan.Pengaruh masing-masing variabel bebas terhadap variabel terikat tersebut dijelaskan sebagai berikut:

Pengaruh Current Ratio terhadap Prediksi Financial Distress Perusahaan

Berdasarkan hasil penelitian ini dapat disimpulkan bahwa ternyata ada beberapa perusahaan yang memiliki $\mathrm{CR}$ yang tinggi akan tetapi perusahaan tersebut tidak mengalami kondisi financial distress. Hasil penelitian ini sejalan dengan hasil penelitian dari Lakshan \& Wijekoon (2017), dan Al-khatib \& Al-Horani (2014), Yudiawati \& Indriani (2016) yang menyatakan 
bahwa CR tidak memiliki pengaruh yang signifikan untuk memprediksi financial distress.

$\mathrm{CR}$ yang tinggi belum tentu menjamin akan dapat dibayarnya hutang perusahaan yang sudah jatuh tempo. Financial distress yang terjadi pada perusahaan tidak hanya ditentukan oleh tinggi atau rendahnya nilai $\mathrm{CR}$ yang dimiliki oleh perusahaan. Perusahaan dengan nilai $\mathrm{CR}$ yang tinggi belum tentu akan terhindar dari financial distress dan perusahaan yang memiliki CR yang rendah juga tidak selalu mengalami financial distress. Ini disebabkan banyak perusahaan yang mengandalkan pendanaan perusahaan untuk membayarkan kewajiban-kewajiban jangka pendeknya dikarenakan perusahaan mempunyai pendanaan perusahaan yang baik, perusahaan tidak akan gegabah untuk menjual atau mencairkan aktiva lancarnya untuk membayarkan kewajiban perusahaan.

Bagi kreditor semakin tinggi rasio lancar berarti semakin aman untuk dirinya. Akan tetapi untuk perusahaan tertentu dapat berarti lain terdapat banyak aspek yang patut untuk menjadi acuan dalam berinvestasi tidak terpaku pada $\mathrm{CR}$ semata. Perusahaan yang mengalami financial distress tidak hanya harus memenuhi kewajiban jangka pendeknya tetapi juga harus memenuhi kewajiban jangka panjangnya, CR hanya menghitung kemampuan perusahaan untuk membayar kewajiban jangka pendeknya saja. Namun ada juga hasil penelitian yang bertentangan dengan hasil penelitian ini yaitu penelitian dari Nindita K, Moeljadi \& Indrawati (2014), dan Ayu (2016) CR berpengaruh signifikan untuk memprediksi financial distress.

\section{Pengaruh Quick Ratio terhadap Prediksi Financial Distress Perusahaan}

Hasil analisis dalam penelitian ini QR tidak berpengaruh atau tidak mampu memprediksi financial distress. Hasil penelitian ini sejalan dengan hasil penelitian dari Lakshan \& Wijekoon (2017), Al-khatib \& Al-Horani (2014), Kariman (2016)menyatakan QR tidak memiliki pengaruh yang signifikan untuk memprediksi financial distress. Berdasarkan data penelitian dapat disimpulkan bahwa ternyata ada beberapa perusahaan yang memiliki QR yang tinggi akan tetapi perusahaan tersebut tidak mengalami kondisi financial distress, sedangkan perusahaan yang dianggap memiliki QR kecil pada periode berikutnya ternyata tidak mengalami tidak mengalami kondisi financial distress.
Sama halnya dengan penjelasan di atas tentang CR, financial distress yang terjadi pada perusahaan tidak hanya ditentukan oleh tinggi atau rendahnya nilai $\mathrm{QR}$ yang dimiliki oleh perusahaan. Perusahaan dengan nilai QR yang tinggi belum tentu akan terhindar dari financial distress dan perusahaan yang memiliki $Q R$ yang rendah juga juga tidak selalu mengalami financial distress. Ini disebabkan banyak perusahaan yang mengandalkan pendanaan perusahaan untuk membayarkan kewajiban-kewajiban jangka pendeknya dikarenakan perusahaan mempunyai pendanaan perusahaan yang baik, perusahaan tidak akan gegabah untuk menjual atau mencairkan aktiva lancarnya untuk membayarkan kewajiban perusahaan. Bagi kreditor semakin tinggi rasio lancar berarti semakin aman untuk dirinya. Akan tetapi untuk perusahaan tertentu dapat berarti lain terdapat banyak aspek yang patut untuk menjadi acuan dalam berinvestasi tidak terpaku pada $Q R$ semata. Perusahaan yang mengalami financial distress tidak hanya harus memenuhi kewajiban jangka pendeknya tetapi juga harus memenuhi kewajiban jangka panjangnya, $Q R$ hanya menghitung kemampuan perusahaan untuk membayar kewajiban jangka pendeknya saja. Namun ada juga hasil penelitian yang bertentangan dengan hasil penelitian ini yaitu penelitian dari Ayu (2016) serta Gilbert dan Edmond (2009) QR memiliki pengaruh signifikan untuk memprediksi financial distress.

\section{Pengaruh Return on Investment terhadap Prediksi Financial Distress Perusahaan}

Hasil analisis dalam penelitian ini ROI berpengaruh secara signifikan terhadap kondisi financial distress. Hasil penelitian ini sejalan dengan hasil penelitian dariLakshan\& Wijekoon (2017), Al-khatib \&Al-Horani (2014), Kariman (2016),dan Simanjuntak C, Titik F, Aminah W (2017) ROI memiliki pengaruh signifikan untuk memprediksi financial distress.

Berdasarkan data penelitian ini berarti bahwa semakin merugi perusahaan maka semakin tinggi potensi perusahaan mengalami financial distress. Artinya semakin rendah kemampuan perusahaan dalam memperoleh keuntungan maka potensi perusahaan mengalami financial distress semakin besar. Namun ada juga hasil penelitian yang bertentangan dengan hasil penelitian ini yaitu penelitian dariKeener (2013) menyatakan ROI tidak memiliki pengaruh signifikan untuk memprediksi financial 
distress.Pengaruh Return on Equity terhadap Prediksi Financial Distress Perusahaan

Hasil analisis dalam penelitian ini ROE tidak berpengaruh secara signifikan terhadap prediksi financial distress. Hasil ini tidak sesuai dengan teori signalling yang mengindikasikan dengan adanya ROE, menunjukkan kesuksesan manajemen dalam memaksimalkan tingkat pengembalian investasi. Investor tidak begitu memperhatikan informasi peningkatan ROE dalam pengambilan keputusan untuk melakukan investasi diperusahaan. Sehingga ROE tidak banyak mempengaruhi keputusan investor dalam berinvestasi. Selain itu kemampuan perusahaan memperoleh laba, dan kemampuan untuk mengendalikan seluruh biaya-biaya operasional dan non-operasional merupakan faktor lain yang bisa jadi pertimbangan. Hasil penelitian ini didukung oleh Lakshan \& Wijekoon (2017) serta Keener (2013) menyatakan ROE tidak memiliki pengaruh yang signifikan.

\section{Pengaruh Debt to Equity Ratio terhadap Prediksi Financial Distress Perusahaan}

Hasil analisis dalam penelitian ini DER tidak berpengaruh secara signifikan terhadap kondisi financial distress. Hasil penelitian ini menunjukkan bahwa informasi perubahan DER sebagaimana bisa diperoleh dari laporan keuangan tidak berpengaruh terhadap keputusan investor dalam berinvestasi. Investor tidak memandang penting penggunaan hutang maupun pengembalian bunga dan pokok hutang yang pada akhirnya tidak mempengaruhi persepsi investor terhadap keuntungan dimasa mendatang.

DER bukan berarti merupakan pertimbangan utama investor dalam memutuskan untuk berinvestasi terdapat faktor eksternal seperti pertumbuhan ekonomi, prediksi pertumbuhan bisnis yang baik, trend yang terjadi dipasar dan lain sebagainya akan membuat investor lebih mengkesampingkan resiko yang akan dihadapi dan lebih fokus pada profitabilitas perusahaan dalam mendapatkan keuntungan. Tidak berpengaruhnya DER terhadap financial distress hal ini mengindikasikan bahwa sebagian besar investor menginginkan laba jangka pendek berupa capital gain dalam mempertimbangkan DER perusahaan ini dikarenakan kebanyakan orientasi investor adalah capital gainoriented bukan dividend oriented. Hal ini sejalan dengan hasil penelitian dari Adel et al (2016),dan Ruslinawati (2017) Debt to equity ratio tidak memiliki pengaruh yang signifikan untuk memprediksi financial distress. Namun ada juga hasil penelitian yang bertentangan dengan hasil penelitian ini yaitu penelitian dari Lakshan \& Wijekoon (2017), Alkhatib \& Al-Horani (2014), Gilbert \& Edmond (2009), dan Keener (2013) debt to equity ratio tidak memiliki pengaruh signifikan untuk memprediksi financial distress.

\section{Pengaruh Debt to Asset Ratio terhadap Prediksi Financial Distress Perusahaan}

Hasil penelitian ini menyatakan tidak ada hubungan atau tidak ada pengaruh signifikan DAR terhadap financial distress. Hasil penelitian ini tidak sesuai dengan logika teori yang telah dipaparkan sebelumnya yang mengatakan bahwa semakin besar jumlah hutang maka semakin besar pula potensi perusahaan akan mengalami kesulitan keuangan dan kebangrutan. Namun hasil penelitian ini sejalan dengan penelitian yang dilakukan belumnya oleh Bhunia \& Sarkar (2011) dan Widhiari \& Merkusiwati (2015) DAR tidak memiliki pengaruh signifikan untuk memprediksi financial distress.

Terdapat banyaknya faktor fundamental lain seperti struktur modal suatu perusahaan, kinerja keuangan perusahaan dan lainnya juga dapat mempengaruhi nilai perusahaan. Oleh karena itu, pihak manajemen perusahaan juga harus mengelola perusahaan dengan baik agar dapat mengendalikan kondisi perusahaan serta dapat mempertahankan kelangsungan hidup perusahaan.Namun ada juga hasil penelitian yang bertentangan dengan hasil penelitian ini yaitu penelitian dariArdian, Andini \& Kharis (2017), Utami (2015) memiliki pengaruh signifikan untuk memprediksi financial distress.

\section{Kesimpulan, Keterbatasan, dan Saran}

Prediksi financial distress sebagai peringatan awal sangat penting untuk mengantisipasi financial distress di perusahaan. Untuk itu diperlukannya model sistem peringatan untuk mengantisipasi adanya financial distress, karena model ini dapat digunakan sebagai sarana untuk mengidentifikasikan bahkan untuk memperbaiki kondisi sebelum sampai pada kondisi krisis. Penelitian ini dilakukan bertujuan untuk menguji kondisi likuiditas (current ratio, quick ratio), profitabilitas (return on investment, return on equity) dan leverage perusahaan (debt to equity ratio, debt to asset ratio)dan pengaruhnya terhadap prediksi financial distress pada perusahaan. Hasil pengujian hipotesis mununjukkan bahwa variabel return on 
investment (ROI) berpengaruh signifikan terhadap financial distress perusahaan. Sedangkan variabel current ratio $(\mathrm{CR})$, quick ratio $(\mathrm{QR})$, return on equity (ROE), debt to equity ratio (DER) dan debt to asset ratio(DAR) tidak berpengaruh terhadap financial distress perusahaan.

Penelitian ini memiliki beberapa keterbatasan yang dapat memengaruhi hasil penelitian. Keterbatasan dalam penelitian ini antara lain dalam memproksikan financial distress hanya berdasarkan cashflow, net operatifincome dan earning per share saja, sehingga masih terbuka kemungkinan adanya alat ukur lain yang mampu memproksikan kondisi financial distress.Untuk penelitian selanjutnya juga diharapkan menggunakan rasio keuangan lain yang mampu memprediksi financial distress seperti rasio arus kas, rasio aktivitas, dan rasio-rasio keuangan yang lain, sehingga tidak terbatas rasio likuiditas, rasio profitabilitas dan rasio leverage perusahaan.

\section{Daftar Referensi}

Arlyana, A., Astuti, R. I., \& Oktapiani, R. (2015). Pemilihan Early Warning Indicator Untuk Mengidentifikasi Distress Sektor Korporasi: Upaya Penguatan Crisis Prevention.

Al-Khatib, H. B., \& Al-Horani, A. (2012). Predicting financial distress of public companies listed in Amman Stock Exchange. European Scientific Journal, ESJ, 8(15).

Altman, E. I., \& Hotchkiss, E. (2010). Corporate financial distress and bankruptcy: Predict and avoid bankruptcy, analyze and invest in distressed debt (Vol. 289). John Wiley \& Sons.

Ardian, A. V., Andini, R., \& Raharjo, K. (2017). Pengaruh Rasio Likuiditas, Rasio Leverage, Rasio Aktifitas Dan Rasio Profitabilitas Terhadap Financial Distress (pada perusahaan manufaktur yang terdaftar di Bursa Efek Indonesia periode tahun 2013-2015). Journal Of Accounting, 3(3).

Ayu, A. S., \& Handayani, S. R. (2017). Pengaruh Likuditas, Leverage, Profitabilitas, Dan Ukuran Perusahaan Terhadap Financial Distress Studi pada Perusahaan Manufaktur Sektor Industri Dasar dan Kimia yang Terdaftar di Bursa Efek Indonesia tahun 2012-2015. Jurnal Administrasi Bisnis, 43(1), 138-147.
Bhunia, A., \& Sarkar, R. (2011). A study of financial distress based on MDA. Journal of Management Research, 3(2), 1.

Brigham, E. F., \& Houston, J. F. (2006). Dasardasar Manajemen Keuangan, edisi kesepuluh. Jakarta: Salemba Empat.

Darsono, A. (2005). Pedoman Praktis Memahami

Keuangan. Yogyakarta: Andi.

Handayani, S. R. (2013). Pengaruh Beberapa Rasio Keuangan terhadap Prediksi Kondisi Financial Distress. Jurnal administrasi bisnis, 1(2), 10-20.

Ijaz, M. S., Hunjra, A. I., Hameed, Z., \& Maqbool, A. (2013). Assessing the financial failure using Z-Score and current ratio: A case of sugar sector listed companies of Karachi Stock Exchange.

Kamaludin, K., \& Pribadi, K. A. (2011). Prediksi financial distress kasus industri manufaktur pendekatan model regresi logistik. In Forum Bisnis Dan Kewirausahaan Jurnal Ilmiah STIE MDP (Vol. 1, No. 1, pp. 11-23). STIE MDP.

Kariman, R. (2016). Prediksi Kondisi Financial Distress dengan Mengguanakan Multiple Discriminant Analysis pada Perusahaan yang Terdaftar di Bursa Efek Indonesia. Skripsi. Universitas Negeri Yogyakarta.

Keener, M. H. (2013). Predicting The financial failure of retail companies in the united states. Journal of Business \& Economics Research (Online), 11(8), 373.

Kriscahyadi, Herdy Tedjo. (2011). Analisis Pengaruh Free Cash Flow, Cash Position, Debt to Equity Ratio dan Company Size terhadap Devidend Payout Ratio pada Perusahaan Manufaktur di BEI Tahun 2008-2010. Jurnal Akuntansi. Vol. 4 No. 5: 81-96.

Lakshan, A. I., \& Wijekoon, W. M. H. N. (2017). The use of financial ratios in predicting corporate failure in Sri Lanka. GSTF Journal on Business Review (GBR), 2(4).

Mbanwie, G., \& Edmond, N. (2009). Financial Rations as Bankruptcy Indicators: The case of Financially Distressed Firms in Sweden. rapport nr.: Master Degree Project 2009: 34.

Nindita, K., \& Indrawati, M. N. K. (2014). Prediction on Financial distress of Mining 
Companies Listed in BEI using Financial Variables and Non-Financial Variables. European Journal of Business and Management, 6(34).

Ruslinawati, Hilda Ayu Devi (2017). Pengaruh Rasio Keuangan Terhadap Financial Distress Pada Perusahaan Manufaktur Yang Listing di BEI 20112015Undergraduate thesis, Universitas Islam Negeri Maulana Malik Ibrahim.

Sawir, A. (2009). Analisa Kinerja Keuangan dan Perencanaan keauangan Perusahaan, PT. Gramedia Pustaka Utama, Jakarta. Simposium Nasional Akuntansi VI.

Shanjaya, A. R., \& Marlius, D. (2017). Peranan Laporan Keuangan Dalam Kebijaksanaan Pemberian Kredit Kepada Calon Nasabah Pada PT. BPR Batang Kapas.

Simanjuntak C, Titik F, Aminah W (2017). Pengaruh Rasio Keuangan Terhadap Financial Distress (Studi Pada Perusahaan Transportasi Yang Terdaftar di Bursa Efek Indonesia 2011-2015.. eProceeding of Management : Vol.4, No.2 Agustus 2017.

Sutrisno, H. (2009). Manajemen keuangan teori, konsep dan aplikasi. Yogyakarta: Ekonosia.

Utami, M. (2015). Pengaruh Aktivitas, Leverage, Dan Pertumbuhan Perusahaan Dalam Memprediksi Financial Distress. Jurnal Akuntansi Universitas Negeri Padang, 3(1).

Widarjo, W., \& Setiawan, D. (2009). Pengaruh rasio keuangan terhadap kondisi financial distress perusahaan otomotif. Jurnal bisnis dan akuntansi, 11(2), 107-119.

Widhiari, N. L. M. A., \& Merkusiwati, N. K. L. A. (2015). Pengaruh rasio likuiditas, leverage, operating capacity, dan sales growth terhadap financial distress. $E$ Jurnal Akuntansi, 456-469.

Yudiawati, R., \& Indriani, A. (2016). Analisis Pengaruh Current Ratio, Debt To Total Asset Ratio, Total Asset Turnover, Dan Sales Growth Ratio Terhadap Kondisi Financial Distress (Studi Kasus Pada Perusahaan Manufaktur Yang terdaftar Di BEI Tahun 2012-2014). Diponegoro Journal of Management, 5(2), 379-391. http://www.idx.co.id/ 
